\title{
New directions in conflict research \\ from an economics perspective
}

\author{
Syed Mansoob Murshed'
}

\begin{abstract}
This chapter begins by looking at the causes of internal conflict in developing countries, reviewing the rational choice debate between greed and grievance as a cause of conflict. It argues that these explanations may be complementary, and the breakdown of the institutions behind conflict resolution, or the social contract, may explain why large scale internal conflict breaks out. It looks at the relationship between globalisation and conflict, bearing in mind that civil war is only one form of violent organised internal conflict, and the fact that the relationship between economic progress, and the risk of conflict may be non-linear, with both growth and the absence of growth producing conflict risk. It then closely examines the relationship between natural resource endowment and conflict risk, arguing that economic dependence on certain types of resources and its associated weak institutions are more likely to produce conflict. The growing prevalence of sectarian and civilisational conflict is also outlined, along with the argument for a need for studying conflict at a more local, sub-national level of analysis.
\end{abstract}

Keywords Internal conflict, civil war, social contract, globalisation and conflict, natural resources and conflict.

\section{I INTRODUCTION}

Even an idealist philosopher like Immanuel Kant (1795) considered war to be the natural state of man. In that respect, he shared the perspective of the English philosopher Thomas Hobbes (1651). According to Hobbes, the state of nature was characterised by anarchy akin to perpetual war. Life was "solitary, poor, nasty, brutish and short" (Hobbes 1651: 84). Consequently, self-interest dictated that individuals should relinquish their personal freedom to an absolute ruler who could ensure personal security and rule based interactions in society. Kant was concerned more with the prevention of war between nations. That would require the simultaneous adoption of a republican constitution by all nations, which inter alia would check the war-like tendencies of both monarchs and the citizenry; the cosmopolitanism that would emerge among the

\footnotetext{
${ }^{1}$ Professor of Economics of Sustainable Development at the International Institute of Social Studies (ISS), Erasmus University, Rotterdam Netherlands, and Coventry University, UK (Corresponding author: murshed@iss.nl).
} 
comity of nations would preclude war, implying a confederation amongst such nation states (foedus pacificum). Kant's notion of cosmopolitanism is also applicable within nation states. Both thinkers were concerned with mechanisms that would engender peace. In other words, peace has to be achieved through deliberate design; this is what Galtung (1964) described as the negative peace (the absence of war).

Within nation states, civil war is only one manifestation of large-scale violent conflict. It is important to emphasise that civil 'war' involves the direct participation of the state and military style confrontations. Since the end of the cold war, conflict research has been dominated by the study of civil war in developing countries and in the former Soviet bloc. One of the factors that contribute to the gestation of many of these civil wars is natural resources, an issue that becomes central to the causation of civil wars in a variety of guises. These include the violent contestation of valuable natural resource rents, normally restricted to minerals, fuels and narcotic substances. The loss of local control over resource rents and resource use (to central government and the forces of globalisation) is often an important source of the grievances that breed conflict. Also, population growth and climate change can induce neo-Malthusian factors leading to the scarcity of land, forests and water resources for agriculture, forestry or pastoral activities may ignite internal conflict (Homer-Dixon 1999).

The discourse on the nature of civil war has gradually evolved into a discussion of development or state failure, depending upon the disciplinary or political stance of the interlocutors. Coinciding with this, there has been a growing proclivity on the part of Western governments and international organisations to become directly involved in conflict affected developing countries after the demise of the cold war, and the associated undermining of Westphalian state sovereignty.

The number of armed conflicts peaked in 1991, when 52 wars occurred in 38 countries. By 2007, however, this number had declined to 34 wars in 25 countries (Gleditsch 2008). Likewise, associated conflict fatalities are also declining. There is one caveat, the number of Muslim countries experiencing civil war as a proportion of all countries in civil war is rising. Civil (and inter-state) war incidence is on the wane, but other forms of violent conflict may be rising, and these do not always involve the state as a direct participant.

For example, violence associated with democratic transitions in many parts of the developing world is still rife. It has been found that the risk of conflict is higher during transitions from an autocratic to a democratic system and vice versa than in longstanding and established autocracies or democracies (Hegre et al. 2001). Although there has been a marked shift towards democracy in most developing countries since the end of the cold war, and most have adopted the multi-party electoral system to form governments, they still lack adequate constraints on the executive and their electoral systems are fraught with imperfections. We might, therefore, better describe these states as anocracies as opposed to democracies. An anocracy has characteristics of both democracy and autocracy; most developing countries fall into this category, raising conflict risk, as will be seen from the discussion below.

Secondly, the losers of increased globalisation, which widens the gulf between the 'haves and have nots', sometimes transform their protests into violent insurgencies. Rapid globalisation, especially in the form of increased international trade and inward foreign investment has increased income differences between skilled and unskilled workers all over the world (Mamoon and Murshed 2008), and income inequality 
generally (Milanovic 2011). In many developing societies, rural hinterlands have been particularly disadvantaged; where it is combined with ethnic differences with the majority of the state's population, this relative backwardness can constitute a recipe for violent (Maoist style) insurgencies. Recent increases in food and fuel prices, coupled with real resources devoted to debt servicing present new vulnerabilities. The important point is that such relative deprivation can take place even when the nation's aggregate economic performance is impressive and growth is both positive and buoyant. Thirdly, there are ethnic or communal conflicts where groups compete over dwindling resources, such as those utilised in agriculture (Homer-Dixon 1999) or other contestable endowments like land. Many of these ethnic conflicts do not include the state as a direct participant.

Contemporary violent internal conflict does not always take the form of civil war; it can be associated with both developmental success and failure, the more acute form of the latter is often referred to as state failure. Mass protest and communal strife are becoming increasingly important forms of internal conflicts in developing countries. Thus, even in successful developing countries and emerging market economies such as India, globalisation and growth can lead to new forms of conflict. Furthermore, democracy does not serve as a panacea for conflict prevention.

This chapter summarises the state of the art on the origins of violent internal conflict in developing countries, highlighting the connection with natural resources. The rest of this work is organised as follows. Section 2 contains an outline of new forms of vulnerability and an integrated theory of conflict and development. Section 3 presents a sketch of the relationships between natural resources and conflict or cooperation. The salience of the local nature of new types of conflict is described in section 4, while section 5 outlines issues in sectarian (communal) conflict based on ethnic difference. Finally, section 6 is by way of conclusion, pointing to certain lacunae in conflict research.

\subsection{CONFLICT AND UNDERDEVELOPMENT/DEVELOPMENT}

Nowadays, organised large-scale conflict in developing countries is almost universally regarded as a source of human development failure, the perpetuation of poverty and human insecurity, all of which enhance the risk of failed states. Equally, endemic poverty and state failure enhance the risk of civil war and conflict. Therefore, the developmental goal of poverty reduction requires conflict prevention. Conflict (even in distant lands) further undermines international security, and thus conflict prevention, abatement and resolution are paramount if the costs of dealing with state failure are to be avoided. Following on, both developmental and security considerations necessitate conflict prevention via human development and poverty reduction. In practice, however, it is difficult to separate the development and security agendas. In 1941, during the Second World War, President Franklin Delano Roosevelt proclaimed four fundamental freedoms. Among these were the freedom from want and the freedom from fear. The former may be regarded as akin to human development. When we combine it with the freedom from fear it helps shape our notion of human security. Once again, these two freedoms are inextricably intertwined, because without security, ensuring livelihoods is meaningless. Likewise, the converse is equally true. In policy 
terms, for example, the reduction of absolute poverty, connected with the millennium development goals (MDGs), yields a double dividend by simultaneously addressing security and developmental concerns.

In the past three decades, and particularly since the end of the cold war, there appears to be a greater incidence of developmental failure and, in the extreme form, state failure, which sometimes leads to violent conflict. Related to these phenomena are the functions of the state. Is the state benevolent or predatory? A great deal has been written on this, but what is salient is that we are increasingly regarding the innate nature of the state in developing countries as factional or predatory. We seem to have left behind the idea that the state should be a functionary agent of society. Even within the predatory category, there are shades of grey associated with good, moderate or bad governance. In many ways, these distinctions among states mirror Olson's (1996) stationary and roving bandit dichotomy. A stationary bandit (state) nurtures the tax base (society) so that more can be extracted in the future, while a roving bandit is only bent on what can be extorted here and now.

\subsection{Causes of conflict risk}

One robust result in the empirical cross-country civil war literature is that per-capita income and conflict risk are significantly and negatively correlated. Although this finding may disguise the mechanisms that truly underlie the statistical association, conflict risk is heavily associated with developmental and state failure. My contention is that both development failure and rapid development (or growth) enhance conflict risk. Additionally, factors external to the nation state can also enhance conflict risk.

Within the rational choice literature on conflict, two broad factors, greed and grievance, have been closely linked to the recent (post-cold war) onset of civil war (see Chapters 3 and 5 in Murshed 2010 for a lengthier elaboration of the arguments that follow in this sub-section). If we were to summarise the greed argument in Collier and Hoeffler (2004), conflict reflects elite competition over valuable natural resource rents, often concealed under the fig leaf of collective grievance. Economic, political and social inequalities play an insignificant role in this process, as these types of grievances are omnipresent in any society. Rather, it is the opportunity afforded by natural resource rents as a ready source of finance for war that is crucial to these forms of violent disputation. There is also a poverty trap in this connection: poverty makes soldiering a less unattractive livelihood strategy, lowering the opportunity cost of war in poor nations. In turn, conflict serves to perpetuate poverty, because of war's destructiveness and a vicious cycle of poverty-conflict-poverty ensues (see, for example, Paul Collier and associates for the World Bank 2003). Fearon and Laitin (2003) assert that civil war risk is mainly associated with diminished state capacity to either deter violent challenges to the state or assuage underlying grievances through transfers and government expenditure. This finding, taken together with Paul Collier's work, has a simple intuitive appeal: civil wars occur in poverty stricken, failed states characterised by venal, corrupt and inept regimes, where the dynamics of war are sustained by a motivation akin to banditry. It also provides the intellectual basis for direct, colonial style intervention in collapsed or failing states.

Against this is a long-standing view that relative deprivation (Gurr 1970) and the grievance that it produces fuels internal violence, although the original argument of 
Ted Gurr pertained more to individual motivation rather than group dynamics. Identity is also crucial to intra-state conflict. Group dynamics require the resolution of the collective action problem, as discussed in Olson (1965). In order to mobilise large groups to undertake collective action and fight other groups, intra-group mistrust, monitoring difficulties and the free-rider problems have to be overcome. Ethnic identities, whether based on race, language, religion, tribal affiliation or regional differences, may serve as a more effective amalgam for the purposes of group formation compared to other forms of difference based on individual inequality such as socioeconomic class. No conflict can proceed without the presence of palpably perceived group differences or grievances, which may have historical dimensions. Frances Stewart (2000) coined the phrase horizontal inequality, the inequality between groups, rather than individual inequality within otherwise homogenous populations (vertical inequality). Crucial here are the more enduring (or hard to change) dimensions of inequality (Tilly 1998), and inequality of opportunity, compared to relatively more transient causes of inequality (like current income), such as the manner in which certain groups are discriminated against, simply because of their ethnic characteristics, as opposed to other personal attributes.

\subsubsection{Social contract}

Ultimately, the greed and grievance motivations for conflict may actually be inseparable. Even if one theory is better at motivating the start of conflict, the other phenomenon is sure to follow. Thus, it is not uncommon for a conflict linked to palpable grievances, for example, to mutate into a situation where the rebels become greedy, and both greed and grievance can be seen to co-exist. It appears that the greed explanation for conflict duration and secessionist wars performs well, in terms of statistical significance, in cross-country studies, but has to make way for grievance-based arguments in country-case studies, even in quantitative analyses. Grievances and horizontal inequalities may, after all, be better at explaining why conflicts begin, but not necessarily why they persist because conflicts require finance, and without internal mechanisms of war finance conflicts may be quickly ended by external intervention (unless the external intervention backs one side in a civil war). Although the presence of either greed or grievance is necessary for the outbreak of violent conflict, they are not sufficient. This requires institutional breakdown for peaceful conflict resolution, which may be described as the failure of the social contract (Murshed 2010). The remainder of this sub-section summarises the arguments therein.

The social contract refers to the mechanisms within society that resolve conflict without outright violence. It contains a moral, economic and political component both at national and local levels. It also implies a functional view of the state: governments exist to serve a purpose, and rule is by consent. Contemporary civil wars are more often related to the breakdown of explicit or implicit mechanisms to share power and resources, rather than the complete absence of an agreement to govern these. This is true even in the most extreme cases of so called state failure, such as in Somalia. Cold war rivalries and the interventions of external powers in the domestic affairs of other countries may also undermine an existing social contract. Among the various factors, two domestic reasons leading to the decline of the social contract deserve special mention. 
The first point refers to the resource sharing agreements. In a well ordered society, some understanding usually exists about sharing revenues and/or expenditure between those in power and others not in power; the breakdown of these arrangements or the undermining of the credibility of existing commitments to resource sharing can produce greed and/or grievance. There are many examples of conflicts that emerge out of fiscal disputes, something that can be exacerbated in the context of economic decline. Disputes over the apportionment of revenues from natural resources are especially common and, as in Nigeria and Indonesia, these often take on ethnic and regional dimensions. Additionally, the social contract is less likely to hold when ruling regimes prefer repression to making transfers that assuage rebellion.

Secondly, there is the political system. Hegre et al. (2001) point out that the risk of conflict is lower in both well-established democracies and autocracies. This suggests that conflict risk is at its greatest during transitions to and away from democracy, when state capacity is weak, and also in fledgling and imperfect democracies (anocracies). State capacity (its ability to both police citizens and provide public goods) is greater in established autocratic or democratic societies, rather than in those somewhere in the middle. Thus, there may be an inverted u-shaped relation between democracy and internal conflict: increased democracy is first associated with rising violence, after a critical point in democratic achievement, conflict and violence diminish. In other words, democratic transitions may induce a greater risk of violence, unless managed well via systems of power sharing and constraints on the executive.

The activities of the state are important in maintaining the cohesiveness of society, which relates to a functioning social contract. In addition to a Weberian monopoly over violence, a functioning state must be able to enforce laws, secure property rights and enforce contracts, as well as possess the fiscal capacity to raise revenues and provide public goods. If it does not, a contradiction emerges between the de jure and de facto functions of the state, which Ghani and Lockhart (2008) label the sovereignty gap. A modern state must also be able to provide a wider range of public goods (health and education for example), in addition to a capacity to regulate and manage markets. The list grows longer with economic progress - more affluent nations tend to have bigger governments (measured by the share of government consumption in national income), as well as greater capacity to tax (see data in World Bank 2010). Economic decline in failing states severely undermines the state's fiscal capacity, something that makes the state heavily development assistance dependent, which further diminishes state capacity. Furthermore, a 'failing' state's ability to guarantee personal security, property rights and laws is often limited, leading to the privatisation of violence between predatory and defensive elements within society. All these factors combine to produce a degenerating social contract, where individuals rely on kinship based groups and local warlords for security and the provision public goods, heightening civil war risk as society descends towards an anarchical, Hobbesian state of nature.

\subsubsection{Globalisation and conflict}

In developing countries deemed to be successes in terms of achieving economic growth and their participation in the globalised economy, economic progress can bring about its own conflictive tendencies even when the state is not fundamentally threatened by outright civil war. Some of these conflicts take the form of highly localised revolts in 
small pockets of the nation state, and may even escape serious international scrutiny, as the country as a whole is deemed to be making progress. Countries that are growth or human development successes on aggregate may still contain regions where extreme disadvantages and deprivation persist.

Some of the world's economic success stories, in terms of growth, are highly globalised in terms of their participation in international trade and financial flows. These countries, mainly in East Asia (and also India), have done well, but the cost has been greater inequality, particularly the widening gap between skilled and unskilled workers (Mamoon and Murshed 2008), and the increased marginalisation of informal sector workers and landless labourers. The Heckscher-Ohlin-Samuelson (HOS) theory of trade informs us that after an expansion of trade, the factors of production engaged more intensively in the exportable sector will witness a rise in their remuneration. This is because the exportable sectors of the economy expand after increased international trade, while the import-competing sectors contract. If there are factors of production, say certain types of workers, specific to the contracting sectors, many of these individuals will become part of the unemployed unless they can re-equip themselves into newer occupations. It is immediately apparent that globalisation produces winners and losers, and in many instances the losers of increased trade or globalisation demand protection. The absence of these counteracting policies can encourage revolt, including violent protest that undermines development, even if it is not a serious challenge to the state of the type that produces what is commonly understood to be state 'failure'. For example, the commercial extraction of forestry and mineral resources in India, along with the historical marginalisation of certain ethnicities, have fuelled Maoist insurgencies in that country.

Rodrik (1998) pointed out that more open economies generally tend to have bigger governments. The larger size of government relative to national income is predicated on the need for the state to provide a form of insurance or social safety net against the temporary adverse economic shocks that tend to strike these more open economies with greater frequency, some of which are purely external to the country. For example, the rise in global food and essential fuel prices sparked off revolts in many parts of the world, especially in food and fuel importing developing countries. Shifts in food and fuel prices may also have even been partially responsible for the Arab Spring protests in 2011. By contrast, the Chinese government's fiscal boost following the growth slowdown in the wake of the 2008 recession may have staved off social unrest. Similarly, the achievement of macroeconomic stability may produce conflict. For example, international financial markets require the smooth servicing of a country's external debt, but debt servicing may require belt tightening in terms of competitive devaluation (which raises the cost of imported food and fuel), as well as government spending cuts. This can lead to mass protest and riots. There is thus a trade-off between macroeconomic and political stability (Boyce 2007).

\subsubsection{Prosperity and violence}

More generally, historical accounts suggest that violence and increasing prosperity initially go hand in hand in the early stages of development, but decline thereafter (Bates 2001). Traditional societies may have rules and norms that manage violent behaviour, even making peaceful dispute settlement self-enforcing. An increase in prosperity may 
encourage predatory behaviour in the form of private violence by the less fortunate, or group violence if the collective action problem is resolved. Once growth progresses further, violence must decline to sustain the security of investment, and the state has to perform regulatory and security provisioning functions. Increasing violence may be symptomatic of the return of privatised social violence, precipitated by frustration spawned by greater awareness in the midst of the lack of commensurate individual (rather than national) progress. Gurr's (1970) notion of relative deprivation argues that when people perceive that they have less than their just deserts, they will revolt. This is more likely to occur when the general or average level of prosperity is increasing, but some groups are left behind, as is often the case following globalisation led growth.

Another issue that may produce violence in developing countries, but has received scant attention, is the growing inequality between the richer and poorer nations of the world. Milanovic (2011) demonstrates that the growth effort required for poor countries to catch up, including that for fast growing emerging economies like India, is much greater than expected. Secondly, individual positions in a global income distribution are much more determined by domicile (the country where you work) rather than socioeconomic class or occupation. For example, the income inequality between two similarly qualified doctors working in Britain and Zimbabwe may be greater than the measured inequalities that exist within a single nation state. In an era of widespread informational dissemination about more affluent life styles, disparities between nations may encourage people disaffected by this global inequality of opportunity to revolt against their government's failure to deliver a higher and fairer standard of living. The draconian restrictions on international migration do not help to resolve these tensions.

\subsection{NATURAL RESOURCE ENDOWMENTS AND CIVIL WAR}

The scarcity of resources such as land or water for agriculture or pastoralism may produce conflict. During the last decade, however, the fact that economic dependence on primary goods exports enhances conflict risk became an oft-cited finding in the rational choice literature in conflict studies. Collier and Hoeffler (2004) thus argue that the abundance of natural resource rents is said to lead to the greed motivation for conflict, the idea being that it is easier to purloin profits or rents associated with the production of natural resource based commodities. This result has been subjected to a great deal of scrutiny, and as a consequence has not emerged unscathed. The fact that this simple assertion, based on a non-robust statistical association, needs to be nuanced is now widely accepted; see Murshed, 2010, chapter 3 for a detailed review.

A major concern with the Collier and Hoeffler (2004) econometric work was that it conflated all primary goods exports (the independent variable was primary goods exports as a share of national income) with key lootable or obstructable resources, and excluded illegal substances. To be a source of conflict a natural resource based product needs to be contestable (Ross 2003); prime examples of these are oil, gas, alluvial diamonds and narcotics bases (coca and poppy). Furthermore, there is a measurement issue: do we take into account the total stock of resources in our measurement of conflict risk rather than flows (indicated by production or exports). Additionally, when we differentiate between on-shore and off-shore oil, alluvial and deep mine diamonds, the conflict risks are greater with both on-shore oil and alluvial diamonds (both are 
more obstructable or lootable). Finally, there are issues with sample size and averaging, rendering the econometric findings of Collier and Hoeffler non-robust to variations in coverage.

The availability of lootable and obstructable resource rents may be a better explanation for the longer duration of civil war rather than its actual onset. Natural resource rents can, in and of themselves, also become a source of grievance leading to war and insurgency if local populations feel that they are not getting their fair share of the proceeds of resource rents. Such is the case in the Niger Delta region of Nigeria. It can also cause secessionist tendencies among relatively rich regions that no longer want to share their wealth with their fellow countrymen, as in the case of Aceh in Indonesia.

The greed motivation for conflict discussed thus far is by no means the only explanation. Aptly titled, the resource curse provides another explanation for conflict. The resource curse argues that the presence of substantial natural resource rents retards development through political economy channels. This has a bearing on resource rents as a potential driver of civil war, as civil war is one (violent) form of competition over the right to control resource rents. In a nutshell, the negative effects of resource rents from a political economy perspective arise when it leads to rent seeking and corruption, both of which have a destructive effect on normal productive investment and hence growth. The key mechanism in the middle which transforms resource wealth and rents to a problematic political economy is institutional quality. Kleptocratic motivations may also lead to the deliberate undermining of the institutions that sustain the social contract mentioned above. The important point is that institutional quality is partially historically determined, but they are equally determined by (or endogenous to) natural resource abundance or dependence.

A related question is what do we precisely mean by institutions. In the literature under review here, institutions pertain to the measured quality of governance, and sometimes to the nature of the political system (democracy, autocracy, anocracy, presidential/prime ministerial systems, constraints on the executive). All of these phenomena are numerically measured in various data sets that code and rank institutional quality. Mavrotas, Murshed and Torres (2011) demonstrate that both point-source (mainly mineral and fuels) and a diffuse (agricultural) type natural resource dependence retard the development of democracy and good governance, which in turn hampers economic growth. In this connection good governance may be more salient for economic growth relative to the quality of democracy.

Auty and Gelb (2001) argue cogently that an abundance of natural resource wealth can make the state and society less benevolent and more extractive compared to developmental states that nurture an internationally competitive manufacturing sector, as in North-East Asia. An abundance of resource rents, especially oil and gas rents, can also retard state capacity, especially fiscal capacity. This is because the state is less reliant on taxes as a source of revenue, depending to some extent on royalties associated with oil and gas. This may have a negative impact on democratic development (Ross 2001), as lower levels of taxation imply less accountable government.

Is it natural resource abundance or dependence which is at issue here? A country may be abundant in natural resources, but may not depend as much on these if it has a diversified economy, compared to undiversified resource dependent economies (referred to as the staple trap by Auty and Gelb, 2001). For example, the United States is abundant in many types of natural resources, but is less dependent on them 
compared to say, Nigeria. The former country mainly exports software based products and services within a global value chain, whereas the latter mainly relies on oil exports. Brunnschweiler and Bulte (2009) reject previous arguments that regard natural resource wealth or dependence as the principal culprit for civil war. They speculate that resource dependence (a reliance on primary goods exports rather than simply having a lot of natural resources) may be a manifestation of the failure to grow and diversify as a consequence of conflict, but it does not contribute directly to conflict.

Both the simple minded greed theories based on purely criminal motivations and naive institutional fundamentalism in relation to natural resource rents and conflict risk need a great deal of nuancing to the individual case under scrutiny, so that the mechanisms that contribute to natural resource rents becoming conflict risk enhancing are properly understood. Among the many factors to be considered are the type of natural resource, measurements of their abundance and the economy's dependence on them, variation in the quality of political institutions, the incentives of rulers and the ruling class, and whether rulers deliberately undermine existing institutions to facilitate their kleptocratic ends.

An important dimension missing from the literature on natural resources and conflict is the individual's motivation to participate or refrain from joining rebellion or violent contests over resource rents. This problem is usually brushed under the carpet, even by those constructing theoretical (mathematical) models of resource driven conflict, by stating that the conflict entrepreneur must satisfy the participation constraints of his soldiers (usually by allowing them to loot). Indeed, many studies have indicated that participation in violence is motivated by the lack of alternative employment opportunities and the lack of human capital (education) with which to make a living. In addition to these extrinsic or pecuniary motivations, individuals are also driven by intrinsic motivations, particularly group grievances. As previously indicated, group identity may be salient to revolt and rebellion. An individual's utility may be related to his group identity, specifically the relative position of the group he identifies himself with in the social pecking order; see Akerlof and Kranton (2000). An individual may derive utility from certain normative forms of behaviour appropriate to his identity but considered deviant by other groups, and may even face sanctions from like-minded group members if he/she deviates from them. Memories of historical injustices can play an important part in forming the group identity. This type of behavioural paradigm may be related to solving the collective action problems alluded to earlier, without which organised large-scale violence is impossible.

\subsection{LOCALISED CONFLICT}

In conflict studies at present there is a need to go beyond the results that emerge from 'averaging' across the world's conflicts typical of cross-national studies, where the cases are extremely heterogeneous because conflicts in different parts of the world are lumped together in a single cross-country econometric exercise, to the analysis of conflict at the more homogenous sub-regional and sub-national levels. The study of local conflicts is very much within the mode of the case study approach. The heterogeneous effects of conflict may extend to different areas of the same country, including rural and urban areas. Therefore, more studies of the drivers and consequences of conflict at a more 
local level within nation states are required. Average results that are determined from a cross-section of countries in various parts of the world, combining Latin America, Africa and Asia, may disguise what is salient to an individual conflict in a region within a country. It is also often misleading, leading to one-size-fits-all types of policy prescriptions that can backfire. For example, environmental conflict between different groups over land, access to water and other natural resource based production inputs yield different results when studied locally or in a large N-country cross-sectional analysis. Environmental factors as a source of conflict are found more significant in local case studies, whereas its importance diminishes when examined through the prism of a cross-country analysis. Moreover, in many large developing countries, systematic internal conflict is highly localised and confined to a few small geographical regions. These do not necessarily seriously undermine the central authority of the state, but continue to retard human development in various pockets, even when the nation as a whole is making progress. The various Maoist insurgencies in India are a case in point.

A variety of methodologies can be employed to study local conflicts. One such technique is based on the analysis of household surveys. These are standard nowadays, and among other things are used to gauge information on household consumption, living standards and other socio-economic information, including questions about identity. They are particularly useful in post-conflict settings in order to garner information on household coping strategies, livelihood investment decisions, as well as the salience of group identity based grievances in provoking future conflict. There have been calls for a more microeconomic approach to the study of conflict (for example, Verwimp, Justino and Brück 2009), and this essentially implies studying conflict in particular localities. Another technique, used in geography, involves GIS mapping of conflict flashpoints and the exact location of contested natural resource endowments. For example, Cederman, Weidmann and Gleditsch (2011) find that group differences in per-capita income along with political exclusion help to explain conflict.

Local level household surveys permit the gathering of information on aspects of cognitive psychology involving trauma and some of the tenets of behavioural economics in situations where there has been violence and conflict. This is important, because household preferences may not be exogenous but endogenous to previous experiences, including the trauma of conflict. For rural households and self-employed informal sector workers, consumption and production decisions are inseparable because production and consumption are closely related. Therefore, these households are used to risky decisions and outlays. The presence of armed conflict can add new dimensions into these risks and uncertainties, depending on the duration and intensity of the conflict, as well as perceptions about conflict re-emerging if it has stopped. Here prospect theory rather than expected utility may be more relevant following the traumas of war (Kahnemann and Tversky 1979). Observed behaviour suggests that an uncertain prospect is often judged by the overall prospect of loss or gain rather than its strict pecuniary expected value; risk taking (rather than risk aversion) may be a more common psychological response from positions of loss.

Prospect theory represents a departure from expected utility in that it is a twostage process, and risky ventures are weighted not just by (subjective) probability of the different risky states, but by a more complicated 'decision weighting' process. The first stage of the decision involves an editing phase where a reference point is chosen to evaluate the likely effect of the actual risky investment and framed in terms of specific 
aspects of the highly valued prospect or outcome by the decision maker. In the second stage of evaluation, when the household decides on its type of investments, it may take more risks if the risky project has a high enough decision weight in comparison to the less risky alternative. Decision weighting is related to the probability of an uncertain project bearing fruition, but it also includes the subjective desirability of the outcome, a property that alters less readily in the mind than the more objective probability of success. The point being that taking on more risks is understandable if there is a substantial chance that such investments will lead to the recuperation of particular erstwhile losses. Consequently, a strong desire to retrieve a valued past state as a primary response to trauma and loss may occasionally lead to increased risk taking after experiences of violence. Clearly, there will be some heterogeneity in individual responses to violence; not all traumatised individuals will become risk takers. Subjective perceptions regarding violence are endogenous to the lingering effect of actual past experiences. In decision-making involving the future, these perceptions may impact more on current individual preferences and choice. Individual households may not just be passively coping with the events around them, but can actively react to these events in order to re-shape their future.

The points enumerated thus far in this section pertain to individuals and households. For the study of local conflict, however, the knowledge of local conditions also matters, and these will differ from national level averages and institutions. Local institutions that are of importance are not the national quality of governance and democratic functioning, but instead local politics and social capital, especially the extent of bridging social capital (if any) between antagonists. Furthermore, local economic conditions are crucial to the conflict, and these include group inequalities, poverty profiles, and the abundance or scarcity of agricultural inputs (resources). Above all, what is salient to a local conflict is whether different ethnicities compete over the same resource, or whether they participate in complementary economic activities. For example, conflict risk is much greater when different ethnicities are engaged in the same activity, say agriculture, than when one group are principally farmers and the other retail traders.

Another point of interest in the analysis of local conflict is decentralised governance, particularly fiscal federalism (Murshed 2010). Fiscal federalism devolves government expenditure decisions and/or revenue raising powers to sub-national entities. The revenue aspect may be important, particularly for regions with natural resources as is the case in Indonesia or Nigeria, because it appeases local discontent about regionally generated revenues being siphoned off to central government. Other regional governments may be better able to raise local revenues or even conduct their own borrowing. Decentralisation may also increase the utility of regions able to make their own decisions about local public expenditure. It is therefore important to distinguish between the revenue and expenditure side of fiscal decentralisation and its relation to conflict.

On the expenditure side, a citizen is normally indifferent to which layer of government provides public goods, as long as provision is adequate. Citizens may care about the type of provision in some instances, say about what languages are taught in school, which might vary over different education authorities. Thus, expenditure priorities are subject to political processes. Consequently, it may matter which executive authority (regional or national) or what legislature (regional or national) legislates on spending 
priorities. Related to this is the theory of club goods. As the name suggests, club goods are excludable and voluntary. Only members can benefit from the club good. As with a public good, members of a club share, so the rule for the optimal provision for public goods also applies. The important point here is that many government services are closer to the characteristics of club goods as opposed to pure public goods, particularly at the local level. Furthermore, an outcome closer to the club goods optimum may be achieved with greater local control over public expenditure. Since this implies volition, it may be conflict reducing.

Poorly conceived fiscal federalism or the failure to adapt federalist rules to new and emerging situations (such as natural resource discoveries or debt burdens) can exacerbate latent conflictual tendencies in federations. In countries where minorities are geographically dispersed, other forms of functional federalism or power dividing mechanisms are necessary in addition to fiscal federalism. Fiscal decentralisation might work better in middle income countries with greater revenues to spend on public goods, and in countries where resource rich regions demand financial autonomy. Indeed, Tranchant (2008) empirically demonstrates that fiscal federalism is more successful at reducing conflict risk in countries with superior institutions using the international country risk guide (ICRG) data, implying that better institutional quality means the country has superior governance and more durable political institutions. In particular, nations with malfunctioning institutions often have weak central governments, which encourages violent challenges to it, as well as scenarios in which fiscal decentralisation fails to mollify potential rebels.

\subsection{SECTARIAN AND CIVILISATIONAL CONFLICT}

Rational choice approaches to conflict mainly focus on the material (economic, political) basis for conflict, as well as its material effects on society. There is relatively less on intrinsic and identity-based motivations for conflict - a group cause based on identity that individuals identify with and can fight for. One reason for this is that rational choice approaches often ignore history, concentrating on more immediate circumstances. Secondly, there is relatively less literature originating from the economics discipline on two forms of low intensity violence: civilisational or cultural conflict and sectarian violence. This is perhaps because neither truly undermines the existence of the state. In sectarian conflict the focus should be on individual choices to join or refrain from violence, rather than collective or group choices, as these modes of sectarian conflict are relatively less pre-meditated.

Sectarian violence between religious groups characterises several developing countries: Hindu-Muslim violence in India, and Christian-Muslim violence in Indonesia and Nigeria. These outbreaks are highly localised - confined to certain regions of large countries - and do not fundamentally undermine the state. The state itself is not a target of the violence, unlike in the case of civil war; only localised state functionaries are found to be actors in this form of violence. India has a longer history than either Nigeria or Indonesia in this regard. Brass (2003) points out that Hindu-Muslim sectarian violence, known as communal rioting in India, is not as spontaneous as we are led to believe, but is very much a part of the political process in India - particularly during the rise of Hindu fundamental parties in the post-Nehru era. He also contends that, since 
Muslims are a regular target of such attacks, the attacks should be more appropriately termed as pogroms rather than spontaneous rioting. The easing of sectarian conflict in developing countries requires poverty reduction and the stemming of the inequalities produced by economic globalisation. Declining poverty raises the attractiveness of peaceful income, rather than the earnings related to loot and violence. The inequality produced by globalisation produces richer sectarian individuals who fund communal causes, leaving it to their poorer brethren to enact the violence. Hence, social safety nets and the public provision of health and education that combat poverty and lower inequality are essential. Localised institutional functioning also needs addressing. This includes the often virulently sectarian outlook of local governments, such as the government of the Indian state of Gujarat. Furthermore, getting to know the "other" by way of increasing the bridging social capital between communities is also important in building peace, as are the advantages of peaceful income to individuals.

\subsection{CONCLUSIONS}

In the last decade, our understanding of the processes underlying mass violent internal conflict has progressed to incorporate a greater variety of economic, political and social factors, as well as institutions of conflict management. Methodological differences remain, but analysts of conflict have achieved a degree of consensus that violent internal conflict is mainly brought about by relative deprivation and/or the competition over resources. These tendencies, however, can either be mitigated by good institutional structures of governance or exacerbated by malfunctioning and degenerating institutions (the social contract). Indeed, one of the more robust statistical findings regarding conflict risk is that low per-capita income increases the likelihood of war. This is because lower per-capita income implies greater poverty, along with a greater probability of institutional malfunctioning.

A well functioning social contract manages potential conflict and discourages violent challenges to the state by non-state actors. There are also well known quantitative studies that cover all countries in the world and regard the determinants of internal conflict. The general propositions that emerge are informative, stressing on the one hand the presence of opportunity and feasibility in forming rebel movements, as well as the failure of state capacity to restrain these tendencies. On the other hand, it has long been recognised that deprivation produces rebellion. This relates to the differences between what people have in terms of tangible socio-economic indicators (income, assets including land, access to common property resources, access to public services, education and health), and what they think are their just deserts. If they have less, they may be inclined to rebel. Furthermore, in the absence of corrective policies, this is more likely to cause conflict in more ethnically fragmented societies. The moot point here is whether we are more concerned with individual relative deprivation or ethnically based group relative deprivation as a source of conflict risk.

Yet a variety of lacunae remain in conflict studies. First and foremost is the complex relationship between development and economic progress and conflict risk. Both severe underdevelopment and rapid economic progress can produce conflict risk. The former is associated more with the risk of civil war, while the latter usually associated with mass violent protest and localised rebellion that does not fundamentally 
undermine the position of the state. Attention has to be focused on the distributional consequences of growth. New sources of tension arise in our globalised world because of rising food and fuel prices that intensify existing grievances against the state, burdens of servicing international debt, and through the relative deprivation felt because of the ever-widening gap in living standards between rich and poor countries. Secondly, we have the non-linear impact of increased democratisation on conflict risk. Mature democracies are usually more peaceful, but democratic transitions enhance the chances of violent conflict. This means we have to have a nuanced take on the role of institutions, eschewing the naïve institutional fundamentalism that pervades the contemporary mainstream thinking about long-term development. Thirdly, greater emphasis has to be put on detailed case studies of local conflict. This means a deeper understanding of local economic conditions and social capital. Household surveys, if intelligently designed, can also yield deeper psychological insights on how the trauma of violence affects economic behaviour, as well as gauging the contribution of group identity and group grievances to any future conflict risk. The role of intrinsic motivation in joining movements, particularly the part played by an individual's identification with the cause of a disadvantaged group that he belongs to, deserves much more than the scant and passing attention that it has hitherto received in the rational choice literature on conflict. The study of sectarian (or communal) conflicts in countries such as India, Indonesia and Nigeria deserves more sophisticated study.

In the ultimate analysis, conflict resolution has ubiquitously required justice, and not just the justice that is in the interest of the stronger. In this connection a few words about the new liberal imperialism, which for example favours regime change by direct action, are in order. Just as in the 19th century, the excuse of civilizing the backward is being increasingly used to justify direct intervention in developing country conflicts. Despite the rhetoric, there is a great danger that these actions are much more in tune with the old imperialist objective of controlling the non-European world to the advantage of Europe (the present West), or at the very least in the spirit of colonialism's misplaced 'white man's burden' aim of civilizing the uncivilised; something that has been historically such a resounding failure.

\section{REFERENCES}

Akerlof, G. and R. E. Kranton. 2000. Economics and Identity. Quarterly Journal of Economics 115, no. 3: 715-753.

Auty, R. M. and A. G. Gelb. 2001. Political Economy of Resource Abundant States. In Resource Abundance and Economic Development, ed. R. M. Auty, 126-44. Oxford: University Press.

Bates, R. H. 2001. Prosperity and Violence. New York: Norton.

Boyce, J. 2007. Public Finance, Aid and Post-Conflict Recovery. Working Paper 2007-09, University of Massachusetts-Amherst.

Brass, P.R. 2003. The Production of Hindu-Muslim Violence in Contemporary India. Seattle: University of Washington Press.

Brunnschweiler, C. N. and E. H. Bulte. 2009. Natural Resources and Violent Conflict: Resource Abundance, Dependence and the Onset of Civil Wars. Oxford Economic Papers 61, no. 4: 651-674.

Cederman, L.-E., N. Weidmann and K.-S. Gleditsch. 2011. Horizontal Inequalities and Ethnonationalist Civil War: A Global Comparison. American Political Science Review 105, no. 3: $478-495$. 
Collier, P. and A. Hoeffler. 2004. Greed and Grievance in Civil Wars. Oxford Economic Papers 56, no. 4: 563-595.

Collier, P., L. Elliot, H. Hegre, A. Hoeffler, M. Reynal-Querol and N. Sambanis. 2003. Breaking the Conflict Trap: Civil War and Development Policy. Oxford: Oxford University Press.

Fearon, J. and D. Laitin. 2003. Ethnicity, Insurgency and Civil War. American Political Science Review 97, 1: 75-90.

Galtung, J. 1964. An Editorial. Journal of Peace Research 1, 1: 1-4.

Ghani, A. and C. Lockhart. 2008. Fixing Failed States. Oxford: University Press.

Gleditsch, N. P. 2008. The Liberal Moment Fifteen Years On. International Studies Quarterly 15, no. 4: 691-712.

Gurr, T. R. 1970. Why Men Rebel. Princeton: Princeton University Press.

Hegre, H., T. Ellingsen, S. Gates and N. P. Gleditsch. 2001. Towards a Democratic Civil Peace? Democracy, Civil Change, and Civil War 1816-1992. American Political Science Review 95, no. 1: 17-33.

Hobbes, T. 1651. Leviathan. Reprinted 1998, Oxford: World Classics.

Homer-Dixon, T. F. 1999. Environment, Scarcity, and Violence. Princeton: University Press.

Kahneman, D. and A. Tversky. 1979. Prospect Theory: An Analysis of Decision under Risk. Econometrica 47, no. 2: 263-292.

Kant, I. 1795. Perpetual Peace and Other Essays on Politics, History and Morals. Reprinted 1983, Indianapolis: Hackett Publishing.

Mamoon, D. and S. M. Murshed. 2008. Unequal Skill Premiums and Trade Liberalization: Is Education the Missing Link? Economics Letters 100, no. 2: 262-266.

Mavrotas, G., S. M. Murshed and S. Torres. 2011. Natural Resource Dependence and Economic Performance in the 1970-2000 Period. Review of Development Economics 15, no. 1: 124-38.

Milanovic, B. 2011. The Haves and the Have Nots. New York: Basic Books.

Murshed, S. M. 2008. A Note on the Interaction between Identity Based Fear and Hatred. Peace Economics, Peace Science and Public Policy 14, no. 1, article no. 5.

Murshed, S. M. 2010. Explaining Civil War: A Rational Choice Approach. Cheltenham: Edward Elgar.

Olson, M. 1965. The Logic of Collective Action. Cambridge MA: Harvard University Press.

Olson, M. 1996. Big Bills Left on the Sidewalk: Why Some Nations are Rich, and Others Poor. Journal of Economic Perspectives 10, no. 1: 3-24.

Rodrik, D. 1998. Why do More Open Countries Have Bigger Government. Journal of Political Economy 106, no. 5: 997-1032.

Ross, M. 2001. Does Oil Hinder Democracy. World Politics 53, no. 3: 325-61.

Ross, M. L. 2003. Oil, Drugs and Diamonds: The Varying Role of Natural Resources in Civil Wars. In The Political Economy of Armed Conflict: Beyond Greed and Grievance, ed. K. Ballentine and J. Sherman, 47-70. Boulder, CO: Lynne Rienner.

Sen, A. K. 2008. Violence, Identity and Poverty. Journal of Peace Research 45, no. 1: 5-15.

Stewart, F. 2000. Crisis Prevention: Tackling Horizontal Inequalities. Oxford Development Studies 28, no. 3: 245-62.

Tilly, C. 1998. Durable Inequality. Berkeley: University of California Press.

Tranchant, J.-P. 2008. Fiscal Decentralization, Institutional Quality and Ethnic Conflict: A Panel Data Analysis, 1985-2001, mimeo.

Verwimp, P., P. Justino and T. Brück. 2009. The Analysis of Conflict: A Micro-Level Perspective. Journal of Peace Research 46, no. 3: 307-314.

World Bank. 2010. Financial Structure and Economic Development Database. 